\title{
2-V or not 2-V: That is the question...plus some musings on thinking out of the box
}

\author{
Ralph E. Delius, MD
}

\author{
From the Department of Cardiovascular Surgery, Children's Hospital of Michigan, Detroit, Mich. \\ Disclosures: Author has nothing to disclose with regard to commercial support. \\ Received for publication Feb 27, 2017; accepted for publication March 2, 2017; available ahead of print April 1, \\ 2017. \\ Address for reprints: Ralph E. Delius, MD, Children's Hospital of Michigan, 3901 Beaubien Blvd, Detroit, MI \\ 48201 (E-mail: rdelius@dmc.org). \\ J Thorac Cardiovasc Surg 2017;154:583-4 \\ 0022-5223/ $\$ 36.00$ \\ Copyright (C) 2017 by The American Association for Thoracic Surgery \\ http://dx.doi.org/10.1016/j.jtcvs.2017.03.010
}

Approximately 20 years ago, when I was a senior registrar at Great Ormond Street Hospital in London, Marc de Leval performed a bidirectional Glenn anastomosis in a child with double-outlet right ventricle and a remote ventricular septal defect. The child did beautifully, and was on her way home to Israel in less than a week. This case sparked an interest in looking up the Great Ormond Street Hospital experience with single-ventricle palliation in patients with 2 ventricles. Mr de Leval put a finer point on it, and reduced it to a basic question: Is a complicated 2 ventricle repair better than single ventricle palliation ${ }^{1}$

Two decades later, the question remains unanswered. There have been some studies suggesting that pushing a 2-ventricle repair in patients with a marginal left ventricle increases mortality compared with single-ventricle palliation. ${ }^{2}$ The long-term outcomes of laminar flow-type Fontans, either later tunnel or external conduit, are just now coming to light, but clearly seem to provide better longterm palliation than atriopulmonary-type Fontans. $^{3-5}$ Nevertheless, in virtually all busy practices there are patients with seemingly perfect Fontans who experience protein-losing enteropathy or plastic bronchitis, as well as other sequelae of single-ventricle palliation. The group at Children's Hospital of Boston has clearly come down on the side of 2 ventricles being preferable, and have provided another excellent article on this topic. ${ }^{6}$ This report delivers some clearly defined messages: an elevated left ventricular end-diastolic pressure $\geq 13 \mathrm{~mm} \mathrm{Hg}$ is a risk factor for a suboptimal outcome when pursuing a 2-ventricle strategy and is a better discriminator than anatomic measurements. This is not surprising - anatomy and physiology usually work in tandem-but when they diverge, physiology usually wins the argument. The article also suggests that a 2-ventricle recruitment strategy has worse outcomes in patients with borderline hypoplastic left heart syndrome than in patients with unbalanced atrioventricular canal. ${ }^{6}$ The inference is that using a series of operations to coax left ventricular growth can work, but the keyhole these patients have to pass through is relatively small. As with any research, one can quibble about some findings. The

\section{References}

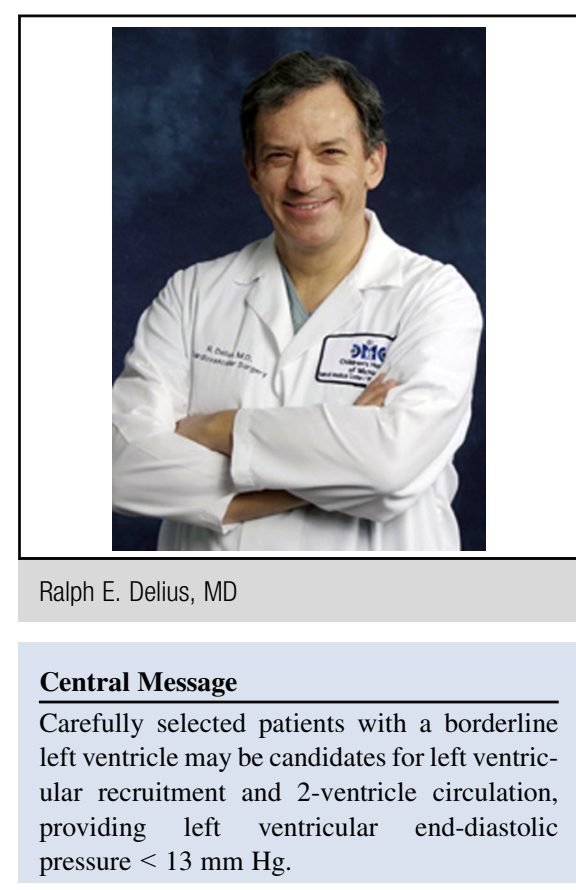

See Article page 572 .

authors suggest that $75 \%$ of patients are not candidates for single-ventricle palliation, but they do not elucidate what those factors are in a given patient. ${ }^{6}$ In a bit of cognitive dissonance, they in turn suggest that single-ventricle palliation is a fallback plan if left ventricular recruitment maneuvers are not successful.

In any event, the article is very well done and clinically useful. I applaud the authors for pushing the envelope on this matter. Their approach is bold, creative, and innovative. In this era of public reporting and hospital administrators wringing their hands over US News and World Report rankings and 3-star ratings, new ideas that entail a degree of risk are often discouraged. One wonders if the conversion from atrial to arterial switch would ever happen in the modern era, given that Mustard/Senning mortality at the time was $\sim 1 \%$ versus a $15 \%$ mortality in early arterial switch series. Despite these prevailing headwinds, the Boston Children's Hospital group has forged ahead and applied a thoughtful and novel approach to this cohort of patients.

1. Delius RE, Rademecker MA, de Leval MR, Elliott MJ, Stark J. Is a high risk biventricular repair always preferable to conversion to a single ventricle repair? $J$ Thorac Cardiovasc Surg. 1996;112:1561-9. 
2. Hickey EJ, Caldarone CA, Blackstone EH, Lofland GK, Yeh T Jr, Pizarro C, et al. Critical left ventricular outflow tract obstruction: the disproportionate impact of biventricular repair in borderline cases. J Thorac Cardiovasc Surg. 2007;134:1429-37.

3. Poh CL, Zannino D, Weintraub RG, Winlaw DS, Grigg LE, Cordina R, et al. Three decades later: the fate of the population of patients who underwent the atriopulmonary Fontan procedure. Int J Cardiol. 2017;231:99-104.

4. Pundi KN, Johnson JN, Dearani JA, Pundi KN, Li Z, Hinck CA, et al. 40-year follow-up after the Fontan operation: long term outcomes of 1,052 patients. $J$ Am Coll Cardiol. 2015;66:1700-10.
5. d'Udekem Y, Iyengar AJ, Galati JC, Forsdick V, Weintraub RG, Wheaton GR, et al. Redefining expectations of long-term survival after the Fontan procedure: twenty-five years of follow-up from the entire population of Australia and New Zealand. Circulation. 2014;130(11 Suppl 1): S32-8.

6. Herrin MA, Zurakowski D, Baird CW, Banka P, Esch JJ, del Nido PJ, et al. Hemodynamic parameters predict adverse outcomes following biventricular conversion with single-ventricle palliation takedown. J Thorac Cardiovasc Surg. 2017;154:572-82. 